Pobrane z czasopisma Folia Bibliologica http:/foliabibliologica.umcs.pl

Data: 26/04/2023 15:50:21

„FOLIA BIBLIOLOGICA” (2019), VOL. LXI

DOI: $10.17951 / \mathrm{fb} .2019 .61 .187-193$

Kinga Dobrowolska

Biblioteka Główna

Uniwersytetu Marii Curie-Skłodowskiej w Lublinie

\begin{abstract}
SPRAWOZDANIE Z DZIAŁALNOŚCI AKADEMICKIEGO KOŁA STOWARZYSZENIA BIBLIOTEKARZY POLSKICH W LUBLINIE W 2019 ROKU
\end{abstract}

Akademickie Koło Stowarzyszenia Bibliotekarzy Polskich (AK SBP) w Lublinie liczyło na koniec 2019 roku 78 członków. Statystycznie ujmując, co czwarty bibliotekarz pracujący w bibliotece uczelni publicznej w Lublinie, tj. Katolickim Uniwersytecie Lubelskim Jana Pawła II (KUL), Uniwersytecie Marii Curie-Skłodowskiej (UMCS), Politechnice Lubelskiej (PL), Uniwersytecie Przyrodniczym (UP), Uniwersytecie Medycznym w Lublinie (UML), to członek AK SBP Lublin.

\title{
Skład Zarządu
}

Skład Zarządu Koła w kadencji 2017-2020 przedstawia się następująco: Anastazja Śniechowska-

-Karpińska (UM)

Bobruk Ewa (UM)

- Przewodniczący

Boćkowska Maria (UP)

- Sekretarz

Butkiewicz Marian (UP)

- Członek

Dobrowolska Kinga (UMCS)

- Zastępca przewodniczącego (do grudnia 2018 r.)

Kasiura Iwona (KUL)

- Zastępca przewodniczącego (od grudnia 2018 r.)

Kontek Janina (PL)

- Członek

Matczuk Ewa (UM)

- Członek (Skarbnik do grudnia 2017 r.)

Pawłowska Anna (KUL)

- Skarbnik (od stycznia 2018 r.)

Wójcik Justyna (PL)

- Członek

- Członek 
Sprawy organizacyjne

W roku 2019 spotkania Zarządu Koła SBP w Lublinie odbywały się w Bibliotece Uniwersytetu Medycznego w terminach:

- 22.03.2019 r. - tematem były plany działania Koła na 2019 r., w tym zamierzenia dotyczące organizacji konferencji, spotkania integracyjnego, warsztatów oraz przedstawienie nominacji do konkursu Lubelski Bibliotekarz Roku;

- 15.11.2019 r. - spotkanie dotyczyło podsumowania działań w 2019 r. oraz planów na kolejny rok.

\section{Działalność naukowa}

Działalność naukowa i szkoleniowa Akademickiego Koła SBP w Lublinie (w tym wydarzenia organizowane we współpracy z Sekcją Bibliotek Naukowych Oddział Lublin):

W roku 2019 zorganizowano następujące imprezy:

1. „Prawo autorskie w edukacji, kulturze i bibliotekach” - warsztaty odbyły się 30.01.2019 r. w godz. 13.30-15.00 w Teatrze NN Ośrodek Brama Grodzka (organizatorami byli AK SBP w Lublinie, Teatr NN Ośrodek Brama Grodzka, Tech Klub Lublin). W wydarzeniu wzięło udział 30 uczestników.

2. „VI Lubelskie Forum Bibliologów, Informatologów i Bibliotekarzy - Infrastruktura bibliotek. Ewolucja przestrzeni bibliotecznej i jej wpływ na jakość usług i wizerunek placówki" - konferencja odbyła się 28 marca 2019 r. w godz. 9.30-15.00 w Sali Obrad Rady Wydziału Humanistycznego UMCS w Lublinie (organizatorami byli: Instytut Informacji Naukowej i Bibliotekoznawstwa UMCS, WBP im. H. Łopacińskiego, SBP Zarząd Okręgu w Lublinie, Akademickie Koło SBP w Lublinie, Sekcja Bibliotek Naukowych SBP Odział Lublin, Sekcja Bibliotek Publicznych przy Zarządzie Głównym SBP). Liczyła 104 uczestników.

W trakcie Forum zaprezentowano działalność Akademickiego Koła SBP w Lublinie (fot. 1).

3. IX Lubelskie Forum Bibliotekarzy odbyło się 15 maja 2019 r. o godz. 10.00 w Wojewódzkiej Bibliotece Publicznej im. H. Łopacińskiego (organizatorami byli: WBP im. H. Łopacińskiego, SBP Zarząd Okręgu w Lublinie, Akademickie Koło SBP w Lublinie, Sekcja Bibliotek Naukowych SBP Odział Lublin, Sekcja Bibliotek Publicznych przy Zarząazie Głównym SBP).

Podczas Forum tytułem Lubelskiego Bibliotekarza Roku 2018 została uhonorowana koleżanka Ewa Matczuk. Nagroda została uroczyście wręczona przez przedstawiciela Zarządu Województwa Lubelskiego Zbigniewa Wojciechowskiego 
Pobrane z czasopisma Folia Bibliologica http:/foliabibliologica.umcs.pl

Data: 26/04/2023 15:50:21

Sprawozdanie z działalności Akademickiego Koła Stowarzyszenia Bibliotekarzy... 189

- w chwili obecnej to jedyna laureatka tej prestiżowej nagrody wśród bibliotekarzy akademickich.

\section{Akademickie Koło SBP w Lublinie}

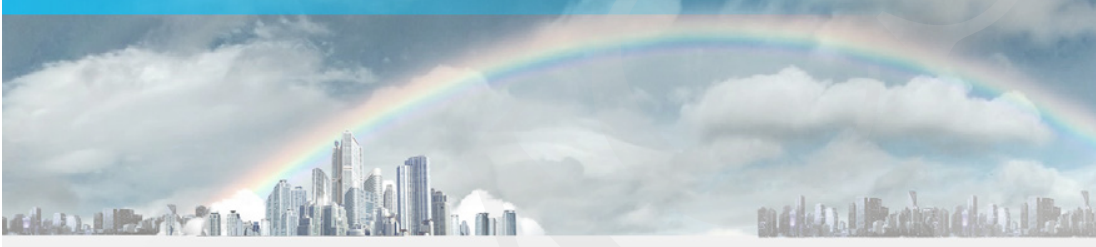

Kinga Dobrowolska

Uniwersytet Marii Curie Skłodowskiej w Lublinie

Fot. 1. Fragment prezentacji.

Źródło: opr. własne.

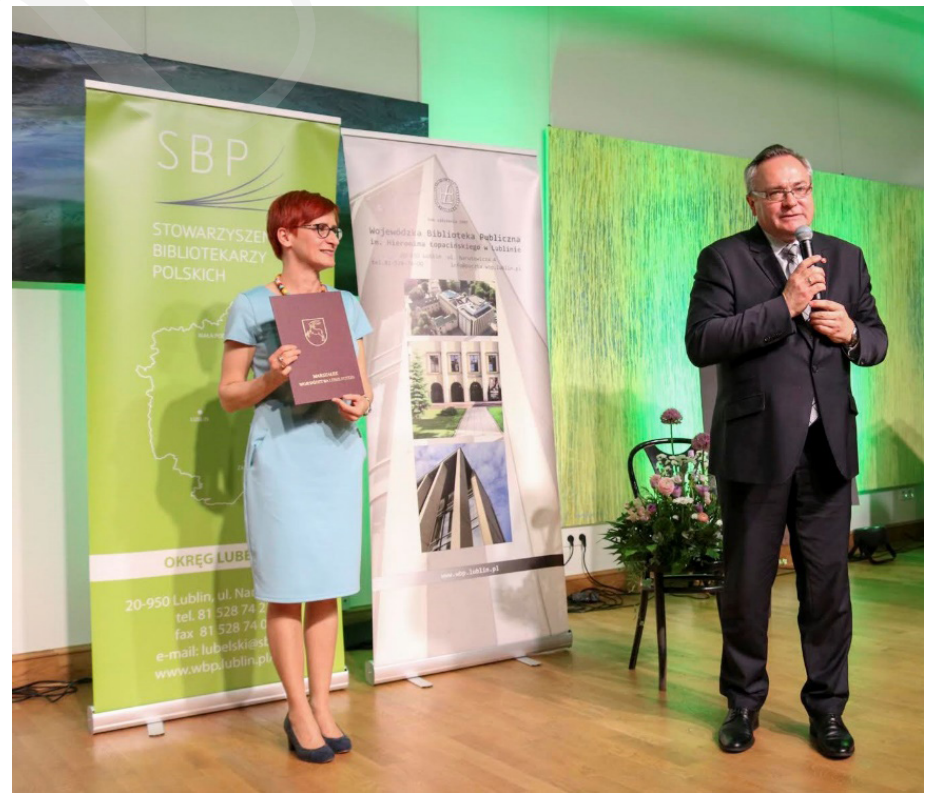

Fot. 2. Wręczenie nagrody Ewie Matczuk przez Zbigniewa Wojciechowskiego członka Zarządu Województwa Lubelskiego.

Źródło: http://hl.wbp.lublin.pl/sbp/ 
4. „Razem! Nie osobno! Biblioteki i kształcenie bibliotekarzy w kontekście Ustawy 2.0" - konferencja odbyła się 27 czerwca 2019 r. w godz. 10.00-15.00 w Sali Obrad Rady Wydziału Humanistycznego UMCS w Lublinie (organizatorami byli: Akademickie Koło SBP w Lublinie, Sekcja Bibliotek Naukowych SBP Oddział Lublin, Instytut Informacji Naukowej i Bibliotekoznawstwa UMCS) (fot. 3).

Sesję plenarną prowadziła dr Krystyna Kwapisiewicz-Hudzik, a dyskusję panelową w drugiej części na temat roli i zadań SBP w kontekście zmian ustawowych poprowadziły dr Renata Malesa i i dr Anastazja Śniechowska-Karpińska. W wydarzeniu wzięło udział 45 osób.

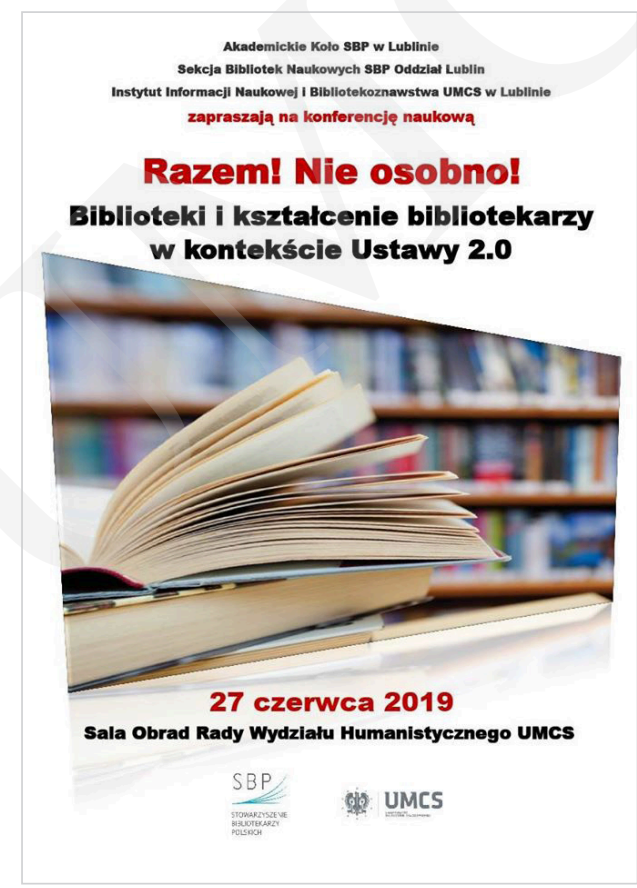

Fot. 3. Plakat konferencji „Razem! Nie osobno!”.

Źródło: https://www.facebook.com/pg/AkademickieKoloSBPLublin/

5. Wykład Joanny Chapskiej „Biblioteka w Hangzhou platformą współpracy bibliotek Europy Środkowo-Wschodniej i Chin”, który odbył się 28.10.2019 r. o godz. 9.00 w Bibliotece Głównej UMCS. Organizatorami byli: Akademickie Koło SBP w Lublinie oraz Biblioteka Główna UMCS (fot. 4). 


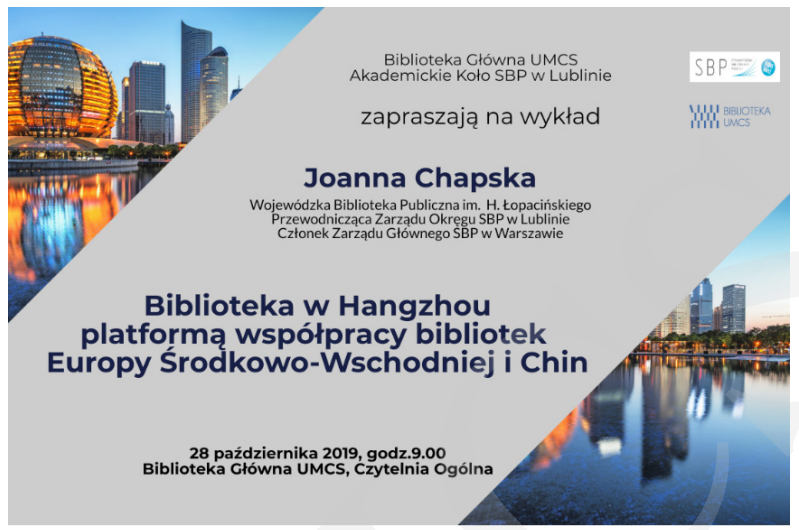

Fot. 4. Zaproszenie na wykład Joanny Chapskiej.

Źródło: https://www.facebook.com/pg/AkademickieKoloSBPLublin/

6. „Prawo autorskie w szkole i bibliotece szkolnej” - warsztaty odbyły się 21 listopada 2019 r. w godz. 16.00-18.00. Organizatorami byli: Teatr NN Ośrodek Brama Grodzka, Akademickie Koło SBP w Lublinie, Sekcja Bibliotek Naukowych SBP Odział Lublin, Biblioteka Główna Uniwersytetu Medycznego w Lublinie. Warsztaty zgromadziły 37 uczestników (fot. 5).

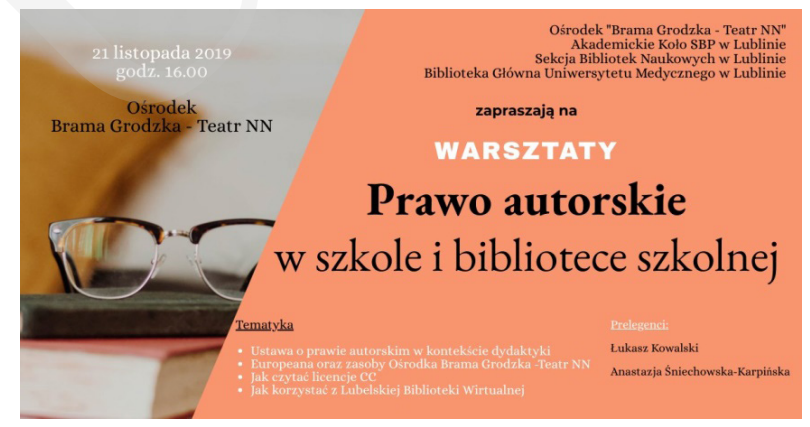

Fot. 5. Zaproszenie na warsztaty „Prawo autorskie”.

Źródło: https://www.facebook.com/pg/AkademickieKoloSBPLublin/

\section{Sukcesy}

Obok laureata Lubelskiego Bibliotekarza Roku 2018 Koło może się poszczycić jeszcze innymi sukcesami, m.in. zgłoszeniem do konkursu Książka Roku pozycji Aktywni i kreatywni: Stowarzyszenie Bibliotekarzy Polskich na Lubelszczyźnie, Lublin Stowarzyszenie Bibliotekarzy Polskich. Zarząd Okręgu w Lublinie, 2018. 
Jednym z redaktorów i autorów zgłoszonej publikacji jest przewodnicząca Akademickiego Koła SBP w Lublinie dr Anastazja Śniechowska-Karpińska.

\section{Działalność popularyzatorska}

Działalność popularyzatorska i integracyjna AK SBP w Lublinie 2019 roku dotyczyła:

- bieżącego prowadzenia strony Akademickiego Koła SBP w Lublinie na FB, na której zamieszczane są informacje o działaniach AK SBP i Sekcji Bibliotek Naukowych - twórcą i administratorem jest Ewa Matczuk. Strona funkcjonuje pod adresem: https://www.facebook.com/AkademickieKoloSBPLublin/;

- podtrzymywania relacji koleżeńskich dzięki wspólnym spotkaniom integracyjnych, m.in. 31 maja 2019 r. w godzinach popołudniowych i wieczornych odbyło się spotkanie w Ogrodzie Botanicznym UMCS.

Pierwsza część obejmowała wycieczkę z przewodnikiem „Śladami roślin biblijnych", a następnie w mniej oficjalnej atmosferze bawiono się przy ognisku. W imprezie zorganizowanej przez Zarząd AK SBP uczestniczyło 36 osób (prawie połowa członków AK SBP zarówno pracujących, jak i emerytów, którzy chętnie uczestniczą we wszelkiego rodzaju spotkaniach);

- dwóch wyjazdów zagranicznych, które są cyklicznie organizowane przez Koło. W roku 2019 Marian Butkiewicz był organizatorem edukacyjnych wycieczek na Morawy (Kromeriż, Brno, Mikulov Ołomuniec) w dniach 26-28.04.2019 r. oraz na Ukrainę i Mołdawię (Poczajów, Tarnopol, Zbaraż, Trembowla, Zaleszczyki, Czerniowiec, Kiszyniów, Tyraspol, Chocim, Kamieniec Podolski, Bukovel) w dniach 29.06-08.07.2019 r.

\section{Wydarzenia}

Wiceprzewodniczącą Sekcji Bibliotek Naukowych przy Zarządzie Głównym SBP została Ewa Matczuk, a członkiem Zarządu Anastazja Śniechowska-Karpińska. Członkami Sekcji Bibliotek Naukowych jest wielu przedstawicieli Akademickiego Koła SBP w Lublinie, aktywnie włączających się w działania Sekcji w Lublinie na rzecz bibliotekarzy lubelskich. 
Sprawozdanie z działalności Akademickiego Koła Stowarzyszenia Bibliotekarzy... 193

\section{Podsumowanie rocznej działalności}

W Bibliotece Głównej UMCS 06.12.2919 r. odbyło się doroczne spotkanie członków SBP, w czasie którego podsumowano działania w roku 2019 i przedstawiono sprawozdanie finansowe oraz plany na 2020 rok. W trakcie zebrania zaprezentowano również relacje $\mathrm{z}$ wizyt zagranicznych, $\mathrm{w}$ których brały udział członkinie Koła:

- VI Międzynarodowy Kongres „The Library as a Cultural Phenomenon - Narodowa Biblioteka Białorusi” - uczestniczyła Anastazja Śniechowska-Karpińska;

- „Inspiracje ze szwedzkiej biblioteki - Erasmus +” - relacja Marii Boćkowskiej.

We wszystkich wydarzeniach organizowanych przez AK SBP wzięło udział około 500 osób. 